\title{
Healing Virtue: Saludadores versus Witches in Early Modern Spain
}

\author{
MARÍA TAUSIET
}

Some saludadores take a glowing coal or red-hot iron in their hand and hold fast to them for a while. Others wash their hands in boiling oil or water. Others walk barefoot over a red-hot iron bar. Others step into hot ovens. ${ }^{1}$

Said one devil: "To see good people, look at the saludadores, who ... claim they do possess virtue." They took offence and said that it was true that they possessed it. And to this replied [another] devil: "How can it be that virtue is found in wanderers who do naught but blow?",

The absence of any clear dividing line between the fields of medicine and religion ${ }^{3}$ in early modern Spain becomes particularly evident when looking at the figure of the socalled saludador (literally, a healer, or health-giver, from the verb saludar, to heal). As the term implies, these individuals claimed to have healing powers-powers that stemmed from the possession of a divine gift or innate grace bestowed upon only a chosen few. The concept of "virtue", understood as both an ability and a moral guarantee, expressed better than any other the widely held belief that disease and sin (and, therefore, health and spiritual perfection) were inextricably linked. ${ }^{4}$ Rather than operating at an individual and self-reflective level, this implicit assumption meant that both the causes of and cures for many illnesses were attributed to the qualities of good or evil of certain external agents supposedly endowed with extraordinary powers. Of these, the most prominent were, without doubt, witches and saludadores.

The success of saludadores was based not only on curing disease, but also on pointing to its cause, and in particular, to discerning the influence of evil spells and witchcraft. ${ }^{5}$

\footnotetext{
1 “Algunos saludadores toman un carbón o hierro encendido en la mano y lo tienen por un rato. Otros se lavan las manos en agua o azeyte hirviendo. Otros miden a pies descalços una barra de hierro ardiendo y andan sobre ella. Otros entran en un horno encendido y fuerte." Pedro Ciruelo, Reprobación de las supersticiones y hechicerías (1st ed., 1530), Valencia, Albatros Hispanofilia, 1978, p. 101.

2 "Dijo un diablo: - Para ver buena gente mirad los saludadores, que ... dicen que tienen virtud. Ellos se agraviaron y dijeron que era verdad que la tienen. Y a esto respondió [otro] diablo: - ¿Cómo es posible que por ningún camino se halle virtud en gente que anda siempre soplando?" Francisco de Quevedo, 'Las zahúrdas de Plutón', in Desvelos soñolientos y discursos de verdades soñadas, descubridores de abusos, vicios y engaños en todos los oficios y estados del mundo, Barcelona, 1629 (Obras de Don Francisco de Quevedo y Villegas, Madrid, BAE, vol. 23, 1946, p. 318).

${ }^{3}$ To put the close relationship between medicine and religion in early modern Europe in context, see two works edited by Ole Peter Grell and Andrew Cunningham: Medicine and the reformation, London, Routledge, 1993, and Religio medici: medicine and religion in seventeenth-century England, London, Scolar Press, 1996. For early modern Spain, see Fabián Alejandro Campagne, 'Medicina y religión en el discurso antisupersticioso español de los siglos XVI a XVIII: un combate por la hegemonía', Dynamis, 2000, 20: 417-56.

${ }^{4}$ See Pedro Laín Entralgo, Enfermedad y pecado, Barcelona, Toray, 1961.

${ }^{5}$ For more on the role of the saludador in Europe, see Gábor Klaniczay, The uses of supernatural power: the transformation of popular religion in medieval and early-modern Europe, Cambridge, Polity Press, 1990,
} 
The complementary nature of the myths of witches and of saludadores is obvious: while the former were supposed to be capable of causing harm simply by channelling their will through their gaze, the latter were said to be able to restore people to health with their words, breath or saliva. If evil emanated from a witch's eye, the corresponding cure was to be found in a saludador's mouth. ${ }^{6}$ The "virtue" of the saludador stands in contrast to the evil or venom of the witch. It is therefore hardly surprising that, just as witchcraft was seen as something that essentially concerned women, the role of the saludador was very much a masculine one, as borne out by the belief that the only true saludadores were the seventh sons of couples who had hitherto produced only male offspring. ${ }^{7}$

As proof of their supernatural power to counteract the most serious of illnesses, saludadores were particularly known for curing rabies, or hydrophobia, ${ }^{8}$ a disease principally caused by being bitten by an infected dog. At the time, of course, hydrophobia was very greatly feared, to the point that rabies came to be associated more generally with all sorts of serious illnesses, whatever their origin. Even today, rabiar de dolor in Spanish means to writhe in agony. In the popular imagination, therefore, saludadores were the people who could cure the worst diseases, those resistant to all natural remedies, and which were frequently attributed to some sort of curse. According to the testimony of a woman from Peñaflor (Saragossa), Petronilla, a seven-year-old girl, had died "in agony", because of spells cast by her own mother, María Tolón, who was accused of witchcraft and tried by the episcopal court in 1609:

At eight in the morning, or thereabouts, Petronilla, the daughter of the said María Tolón ... a pretty and happy child, came to the house of the witness to work in the vineyards ... The said Petronilla was suddenly seen to be overcome with vomiting and great pain, which obliged this witness to put her to bed ... and within half an hour she was so ill that ... shaking horribly, her face terribly contorted, she died in agony. ${ }^{9}$

On that occasion there was no time to look for a cure, but other cases dealt with at the same trial and also attributed to spells cast by María Tolón had ended differently. One symptom traditionally linked to witchcraft was known in Aragon as ladrar (literally "barking"), which may refer to the kind of shouts of pain that people afflicted with rabies or simply suffering particularly violent bouts of pain in the course of an unknown illness would

pp. 149-50. For Spain, see Fabián Alejandro Campagne, 'Cultura popular y saber médico en la España de los Austrias', in María Estela González de Fauve (ed.), Medicina y sociedad: curar y sanar en la España de los siglos XIII al XVI, Buenos Aires, Universidad de Buenos Aires, 1996, pp. 195-239; Enrique Perdiguero, 'Protomedicato y curanderismo', Dynamis, 1996, 16: 91-108.

${ }^{6}$ See Robin Briggs, Witches and neighbours: the social and cultural context of European witchcraft, London, Harper Collins, 1996, pp. 171-95; María Tausiet, Ponzoña en los ojos: brujería y superstición en Aragón en el siglo XVI, Madrid, Turner, 2004, pp. 325-46.

${ }^{7}$ See Keith Thomas, Religion and the decline of magic: studies in popular beliefs in sixteenth-and seventeenthcentury England, Harmondsworth, Penguin, 1973, pp. 237-9.

${ }^{8}$ The name comes from one of the condition's best-known symptoms, the difficulty in swallowing, which from ancient times was interpreted as a "dread of water".

9 "A las ocho de la mañana poco más o menos, habiendo venido la hija de la dicha María Tolón llamada Petronilla ... muy hermosa y con mucho contento a casa de la deposante a labrar unas viñas ... vio a la dicha Petronilla le dio de repente unos grandes vómitos y grande mal, que le forzó a esta deposante a hecharla en su cama ... y dentro de media ora le dio tan grande mal que ... murió rabiando y con muy grandes temblores y visages de ojos y cara." Trial of Francisca Castán and María Tolón, Peñaflor, 1609, Archivo Diocesano de Zaragoza, Saragossa, C. 5-10, fol. 164r. 


\section{María Tausiet}

have emitted. The saludadores would be called in to try and cure them. According to further accusations levelled at María Tolón in 1609:

María Tolón ... bewitched a child ... so that he began to bark as if truly he were a dog, and being thus bewitched, and saludadores having been brought to that place to cure him, the child did publicly state that he had been bewitched by the said María Tolón. ${ }^{10}$

The saludadores' job, however, went beyond that of a doctor. They had a wider social function: that of publicly confirming that spells had been cast. A further accusation heard at the same trial stated that one patient "was so ill that he became paralysed and crippled and lay in bed for many days, until he was cured ... by the saludadores of Saragossa, who declared him ... to have been bound and enchanted". ${ }^{11}$

The real work of saludadores, therefore, went beyond diagnosis to the naming of the women supposedly behind the spells or curses, many of whom were then forced to hide or to flee their villages in the face of a threat that could have meant death to them, given the social acceptance enjoyed by their accusers. This acceptance was based on a deeply rooted mythology, according to which the divine grace or virtue possessed by saludadores was manifest in their ability not only to cure the most virulent diseases, but also to challenge all kinds of misfortune. It was said they could drive away storms, combat plagues of locusts, stop fires from spreading, and even "transform beings and things in the manner of the sages of pagan times". ${ }^{12}$ To prove their power, many saludadores claimed to be able to walk barefoot on red-hot iron bars, cool live coals on their tongues, or step inside lit ovens in the presence of those who doubted their abilities. In fact, their supposed immunity to the effects of fire can be traced back to ancient traditions, such as Virgil's tale of Apollo's priests walking over glowing embers on Mount Soracte. ${ }^{13}$

There are, therefore, many parallels between the archetypal images of the witch and the saludador, or "discoverer of evil". The two stereotypes fit into a binary scheme wherein one was embodied by the weaker sex, the other by the stronger; one represented disease, the other health; one suggested diabolical evil, the other natural goodness; one had the evil eye, the other a mouth capable of giving life. Of particular significance here is the idea that both witches and saludadores bore a mark or sign somewhere on the body that distinguished them from the rest of their kind. All the classics of demonological literature have devoted several pages to witches' marks, ${ }^{14}$ since, so it was said, these were made by the devil's claw on each new recruit at a witches' sabbath to seal the pact she had made to bind herself to him.

\footnotetext{
10 “"María Tolón ... embrujó un niño ... de manera que vino a ladrar como si verdaderamente fuera un perro, y estando assí embrujado, y llevando al dicho lugar saludadores para sanar al dicho muchacho, públicamente se dixo que estava embruxado por dicha María Tolón.” Ibid., fol. 17.

11 “Tuvo tan grande mal que se baldó y estuvo tullido y en una cama por muchos días, hasta que fue saludado ... por los saludadores de Çaragoça, los quales publicaron el dicho ... estar ligado y hechiçado." Ibid., fol. 13.

12 “. . . transformar los seres y las cosas a la manera de los magos sabios de la tradición pagana”, Luis S Granjel, Aspectos médicos de la literatura antisupersticiosa española de los siglos XVI y XVII, Salamanca, Universidad de Salamanca, 1953, p. 66.

${ }^{13}$ Virgil, The Aeneid, Book XI. On the symbolism of fire and its curative properties, see Ignazio E Buttitta, Il fuoco: simbolismo e pratiche rituali, Palermo, Sellerio, 2002.

${ }^{14}$ For example, according to Gaspar Navarro, "God removes the wretch from the book of life ... and they give him a new name, and mark him with black marks in the shape of the foot of a cockerel, or a hare, or some other animal". Gaspar Navarro, Tribunal de superstición ladina, Huesca, Pedro Blusón, 1632, fol. 53v.
} 


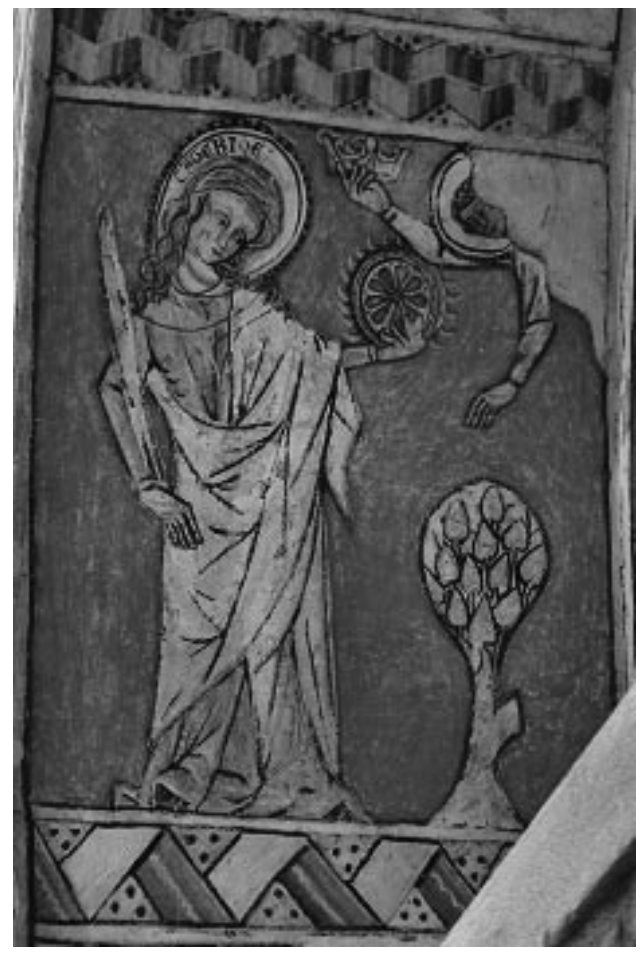

Figure 1: St Catherine holding a palm and a toothed wheel (thirteenth century). Fresco from the church of San Miguel de Foces (Huesca). (Photo by César Hernández.)

\section{Holy and Diabolical Marks}

While witches were believed to have been imprinted by the devil's claw, ${ }^{15}$ the sign most commonly associated with saludadores was that of the wheel of St Catherine, an ancient sun symbol later adopted by Christianity to represent the instrument of torture on which the Alexandrine saint was martyred. ${ }^{16}$ It was thought that most saludadores bore the mark on their hard palate ("on the roof of the mouth", in the words of the Benedictine Benito Jerónimo Feijoo [1676-1764]), although there were also those who claimed to have the "mark of St Quiteria" (the curer of rabies) or the image of a crucifix beneath their tongues. ${ }^{17}$

\footnotetext{
${ }^{15}$ See François Delpech, 'La "marque" des sorcières: logique(s) de la stigmatisation diabolique', in Nicole Jacques-Chaquin and Maxime Préaud (eds), Le sabbat des sorciers en Europe (XV ${ }^{e-X V I I I}{ }^{e}$ siècles), Grenoble, Jérôme Millon, 1993, pp. 347-68.

${ }^{16}$ The learned bibliophile Antonio de Torquemada said of the saludadores: "they say that they can be recognized by the wheel of St Catherine on their palate or some other part of the body". Antonio de Torquemada, Jardín de flores curiosas (1st ed., 1570), Madrid, Castalia, 1982, p. 324.

${ }^{17}$ Benito Jerónimo Feijoo, Teatro crítico universal (1st ed., 1729), 8 vols, Madrid, Real Compañía de Impresores y Libreros, 1777, vol. 3, pp. 1-18.
} 


\section{María Tausiet}

The saludadores' mark was clearly positive in nature, like the stigmata borne by some saints or the birthmarks of certain kings and miracle-workers. ${ }^{18}$ Like other evidence of the possession of virtue (such as being the seventh son, having been born on Christmas Eve or Good Friday, or even being of royal blood ${ }^{19}$ ), the mark was seen as innate, and took on an astral, shining form. It acted as a symbol of the igneous nature of people who claimed to be fireproof, whose warm breath could cure the fearful disease of rabies. Witches, on the other hand, were not born with their marks, but acquired them on making the diabolical pact. Moreover, the animal-shaped form of their marks was indicative of base instincts and terrible vice, in contrast to the high designs suggested by symbols of celestial bodies.

Ultimately, all the theories about such marks simply reflected the belief, so prevalent at the time, in the lack of distinction between body and soul. Bodily marks, whether positive or negative in meaning, were thought to be an external manifestation of the bearer's psychological characteristics. People were so convinced of the power of the imagination that they believed its effects could be real and physical, and so might well appear imprinted on the skin of those beings remarkable for either their virtuous or their sinful nature. It was no coincidence that the ancient sciences of physiognomy (from the Greek physis, nature, and gnosis, to know) and metoposcopy (from métopon, forehead, and skopéo, to examine) were resurrected in Europe during the sixteenth and seventeenth centuries. Physiognomy sought to judge an individual's character traits by means of examining the facial features, while metoposcopy was the art of telling the future from the lines on the face. ${ }^{20}$

As well as resonating with Neoplatonic associations, however, the notion of the mark was also, of course, used within the legal system in order to segregate certain elements of society. Jews and lepers, for example, were forced to dress distinctively so as to mark themselves out from other people (from the thirteenth century onwards in particular). ${ }^{21}$ Such distinctions were often confused with the badges of infamy that certain criminals were ordered to wear and, bearing in mind the widespread conviction that a person's outward appearance revealed his or her inner nature, the significance invested by the authorities in such signs is scarcely surprising.

The binary opposition between saludadores and witches reveals the importance given by the legal system to the concept of the mark. A mark could serve as proof that a woman

\footnotetext{
${ }^{18}$ Marc Bloch, Les rois thaumaturges, Paris, Gallimard, 1983; François Delpech, 'Du héros marqué au signe du prophète: esquisse pour l'archéologie d'un motif chevaleresque', Bulletin Hispanique, 1990, 92: 237-57; idem, 'Les marques de naissance: physiognomie, signature magique et charisme souverain', in Augustin Redondo (ed.), Le corps dans la société espagnole des XVI et XVII siècles, Paris, Publications de la Sorbonne, 1990, pp. $27-49$.

${ }^{19}$ As Luis S Granjel notes, "The fact that Philip IV was not only king of Castile but had been born on Good Friday, gave a new boost to the belief . . that the power to cure those possessed and enchanted was, as if by right, linked to the Castilian royalty." ("El que Felipe IV uniese a su carácter de rey de Castilla el haber nacido en Viernes Santo, dio un nuevo aire a la creencia ... de que a la realeza castellana se unía, como por derecho propio, el poder de curar endemoniados y hechizados."), op. cit., note 12 above, p. 66.

${ }^{20}$ Delpech, op. cit., note 18 above, both references; Julio Caro Baroja, Historia de la fisiognómica: el rostro yel carácter, Madrid, Istmo, 1988; Jean-Jacques Courtine and Claudine Haroche, Histoire du visage; exprimer et taire ses émotions (du хvie au début du xixe siècle), Paris, Rivages, 1988.

${ }^{21}$ See Robert Ulysse, Les signes d'infamie au moyen âge, Paris, Honoré Champion, 1891, and Vincent Raymond Rivière-Chalan, La marque infâme des lépreux et des christians sous l'ancien régime, Paris, La Pensée Universelle, 1978.
} 
brought before a judge to face accusations of witchcraft was guilty. As for the saludadores, as "witch-finders" and possessors of charismatic healing powers, they often worked very closely (as did qualified medical practitioners, both physicians and surgeons) with the justice system, specifically the secular courts, as can be seen from a number of documents relating to the region of Aragon. In the words of François Delpech, "more than the inquisitors, those truly obsessed with the mark of the devil were the representatives of civil jurisdiction and the municipal authorities". ${ }^{22}$

It is no accident that diabolical marks were so frequently mentioned in some of the witchcraft trials presided over by secular judges. The majority of allusions recorded come from cases brought before a local judge, and form an integral part of the kind of stereotypical accusations that defendants had to face, such as sabbath participation or infanticide. One such case was that brought against María Vizcarreta by the prosecutor at the secular court of Épila (Saragossa), during which the following was stated:

She was sent for in order to establish whether she was marked, and, with holy water, there was discovered on her the mark of a hand of the shape and nature described in the court papers, in the form of a paw or claw; and to verify this, Pedro de Asta, a surgeon, drove a long iron needle through the centre of the mark, until it met the bone of the shoulder blade, and when she was asked if she felt it, she said she did not. The fact that neither when being taken prisoner, nor since, has she shed a single tear, even knowing herself in the power of an executioner who recognized her, and a surgeon who pierced her shoulder, is indication of her guilt as a witch, deserving of the death penalty. ${ }^{23}$

Witch-hunters believed that the mark of the Devil endowed its bearers with a total insensitivity to pain, especially on the part of the body where the mark itself lay. Since witch trials were seen as occasions for a fight to the death between the forces of good and evil, the implication was that each contender could make use of the weapons at their disposal. Where judges had instruments of torture and overall control of the situation, witches were imputed to have the magical gifts granted them by the Devil, such as, for example, the famous "power of taciturnity", which enabled them to keep their practices secret, ${ }^{24}$ or their ability to withstand violent attacks on the part of the body marked by Satan.

The Devil was also thought to be responsible for an inability to cry, so that a lack of tears even under torture was a further sign of a defendant's guilt. Thus, for example, when María Vizcarreta was given the opportunity to try and exonerate herself, in the so-called "statement of defence" she declared,

\footnotetext{
22 “Plus que les inquisiteurs, les grands obsédés de la marque du diable ont été les représentants des juridictions civiles et des pouvoirs municipaux." Delpech, op. cit., note 15 above, p. 354.

23 “Aviéndola mandado reconocer, por si estava marcada, se le ha descubierto con agua bendita tibia, un señal de mano de la figura y carácter dibujado en el processo, a forma de zarpa o garra; y para verificación Pedro de Asta, zirujano, le hincó por medio del señal una aguja muy grande de yerro, hasta la misma paleta del hueso de la espalda, y preguntándole si lo sentía, dixo que no. Que después de presa, ni hasta aora, no ha echado lágrima alguna, con verse en poder de un verdugo que le reconoció, y un zirujano que le travesó la espalda, indicios todos que la convencen de hechizera, para la pena ordinaria." Trial of María Vizcarreta, Épila, 1651, in José de Sesé, Decisionum Sacri Senatus Regii Regni Aragonum, et Curiae domini Justitiae Aragonum, causarum civilium et criminalium, Saragossa, Joan de Larumbe, 1611-1627, fols. 111-22.

${ }^{24}$ Nicole Jacques-Chaquin, 'Le maléfice de taciturnité. Esquisse d'une étude du mythe de la sorcière', Cahiers de Fontenay, 1978, 9-10: 137-69.
} 


\section{María Tausiet}

That the mark on her back is different from how it was described in the court papers, and that they had placed cupping glasses on her, burned her and injured her. That she has been weeping since she was put in gaol, and that on the day on which the needle was used, no tears could equal the pain and loss of natural senses she endured. ${ }^{25}$

None the less, she was condemned to death, the court considering that she had not "proved anything, nor brought witnesses", and that her claim to be innocent was "unlikely and improbable". ${ }^{26}$ While María Vizcarreta was accused of bearing "the mark of a hand complete with nails", ${ }^{27}$ Dominga Ferrer, "La Coja" ("the cripple")—whom we know to have been tried by the court of Pozán de Vero (Huesca) in 1534—was examined in the presence of the judge and found to possess several marks, described on that occasion as "in the shape of a cat's foot", as reported at her trial:

We saw that the said Domenicha had on her person many signs, among which these three: one on the left leg; another on the muscle of the right arm, which appeared to take the shape of a cat's foot; and another large mark above the knee, it too in the shape of a cat's foot, with its claws deeply marked. ${ }^{28}$

Further evidence that Dominga had made a pact with the Devil was discerned in the fact that she had "no hair in her armpits" and that the flesh of "that place where hair is naturally accustomed to grow" was "purple in colour". Then, in one final experiment, an aberrant form of supposedly objective rationalism:

The said judge ... did order a visual inspection to be carried out to see if tears came from the eyes of the said Domenicha and when they looked to see if she was crying or not, no tears appeared to fall from her eyes. ${ }^{29}$

The episcopal courts held a very different attitude towards all kinds of supposedly diabolical marks. Contrary to what usually happened in the secular courts, the majority of which legitimized as many accusations of witchcraft as came to their attention, diocesan judges carried out genuine investigations, with the result that, in most cases, they drew conclusions free of prejudice, basing their findings on common sense, rather than on a desire to perpetuate the myth of witchcraft. According to the only surviving testimony from an episcopal trial to include a reference to a diabolical mark, that given by Gerónimo Albiol in the case against Susana Dalmau, of Peñarroya de Tastavins (Teruel),

They had seen on a daughter of the said Burguesa, named Catalina Burgués, the sign of a cockerel's foot on her back, as if branded as a mark, and in the village it was heard say that some nights the

\footnotetext{
25 “Que el señal es diferente en las espaldas de cómo está en el processo, y que le echaron unas ventosas, y le quemaron y le hizieron daño. Que ha llorado después que esté en la cárcel, y que el día de la prueva de la aguja no era mucho, ni aun llorar, ni aun tener sentidos naturales." Trial of María Vizcarreta, op. cit., note 23 above, fol. 10.

26 “. . probado cosa alguna, ni traído testigos, ni publicado"; "inverosímil e improbable”. Ibid., fol. 10.

27 “... una señal de mano entera con uñas”. Ibid., fol. 11.

28 “Vimos que la dicha Domenicha tenía en su persona muchos señales, entre los quales tenía tres señales: uno en la pierna izquierda; otro en el musglo del braço drecho, que parescía hecho a modo de rastro de pie de gato; y otro señal grande encima de la rodilla, assí mismo que parescia como rastro de pie de gato, con sus uñas bien fondo." Trial of Dominga Ferrer, "La Coja”, Pozán de Vero (Huesca), 1534, Archivo Histórico Provincial de Huesca, Huesca, C. 31-2, fol. 40.

29 "El dicho señor justicia ... mandavit hazer ocular inspection si salían lágrimas de los ojos de la dicha Domenicha al tiempo que hazía como que lloraba o no, y ningunas lágrimas parescieron que le saliessen de sus ojos." Ibid., fol. 40.
} 


\section{Saludadores versus Witches in Early Modern Spain}

said Burguesa did lift a flagstone from the fire and give herself a push on the buttocks and climb up out of the chimney. ${ }^{30}$

A little further on it was noted that, after listening to this deposition, the notary and the commissioner in charge of the case had ordered the young woman to be brought in to be inspected and the existence of this mark to be proved:

It was and is true that the notary and commissioner before whom and in whose authority the witnesses have sworn their oaths and given their evidence ... to investigate, see, discover and conclude that the daughter of the said Burguesa, known as Catalina Burgués, did and does have the aforesaid sign of the cockerel's foot on her back, did send for and have brought before them the said girl ... and they did strip her and examine her and did look with much curiosity upon her back, investigating and inquiring whether she bore the mark. And never did they find such a mark on her, nor did they see or recognize any sign or trace of it at all, and that is the truth. $^{31}$

In the same way as the demonic marks on the bodies of those accused of witchcraft responded to an imaginary construct, the vast majority of self-styled saludadores possessed none of the abilities mentioned earlier, although they certainly tried to feign them in order to build up a large and loyal clientele. Thus, for example, in 1619 a shoemaker named Gabriel Monteche confessed before the inquisitorial court in Saragossa that

he had held the office of saludador for many years, pretending he had the virtue to cure the bites of rabid dogs, and to cure other sicknesses and to deliver villages from hailstorms, saying that he bore on one arm the wheel of Saint Catherine and on the other a cross, which signs he had made himself with a needle to deceive people and let them think he had been born with them. And he would show them to many people to make them believe he had virtue ... and that he also let it be known he was a seventh son and had the virtue and grace of God. ${ }^{32}$

And the detailed description of the tricks employed by the shoemaker to fool those who came to him for help went further. Gabriel Monteche admitted that he used to put a worm in his mouth and then claim that he had removed it from his patient at the moment of cure:

30 "Havían visto a una hija de la dicha Burguesa, llamada Catalina Burgués, un señal de pie de gallo en las espaldas, como sellado a modo de marco, y que en el lugar ha oydo dezir que la dicha Burguesa algunas noches no haze sino levantar una losa del fuego y darse una palmada en las nalgas y salirse por la chimenea arriba." Trial of Susana Dalmau, Peñarroya de Tastavins (Teruel), 1591, Archivo Diocesano de Zaragoza, Saragossa, C. 74-30, fols. $31 v-32 r$.

31 "Fue y es verdad que el notario y comisario ante quien y en cuyo poder han jurado y deposado los asertos testigos ... para indagar, ver, descubrir y sacar en limpio que la hija de dicha Burguesa, llamada Catalina Burgués, tenía y tiene el sobredicho señal de pie de gallo en las espaldas, mandaron y hizieron traer ante sí dicha muchacha ... y desnudar aquélla, y la reconocieron y miraron con mucha curiosidad las espaldas, indagando y inquiriendo si tenía dicho señal de pie de gallo. Y jamás le hallaron tal señal, ni vieron ni conocieron indicio ni rastro alguno dello, y assí es verdad." Ibid., fols. 32r-v.

32 "Avía hecho officio de saludador muchos años, fingiendo que tenia virtud para curar mordeduras de perros raviosos, y para curar de otras enfermedades y librar los terminos de piedra, diziendo que tenía en un braço la rueda de Santa Catalina y en otro braço una cruz, las quales se avía hecho con una aguja para engañar y dar a entender que avía nacido con ellas. Y que las enseñava a muchos para que creyesen que tenía virtud ... y que asímismo dava a entender que era hijo sétimo y que tenía virtud y gracia de Dios." Account of the trial of Gabriel Monteche, Saragossa, 1619, Archivo Histórico Nacional, Madrid, Inquisición, Libro 991, fol. 435v. 


\section{María Tausiet}

He would put a worm in his mouth, and let it be thought by those who had been touched by rabid dogs that he was a saludador and that he would heal them. And he would have a surgeon pierce the patient's skin, allowing a little blood to spill, and then he would come, suck that blood, and afterwards add it to a bowl of water and, having stirred the two, would add the worm from his mouth, and as it was mixed with the blood that he had sucked, they thought and believed that he had taken it from the man's body, and they gave him money and held him to be a saludador who by the grace of God could carry out such cures. ${ }^{33}$

Finally, in his declaration before the inquisitors, Gabriel had no hesitation in blaming his verbal excesses on alcohol, as well as openly admitting that everything he had done

was fraudulent, done to cheat and make money, and that all those who went around healing were doing the same thing, deceiving people and pretending they had a special gift from God. And he declared that he would also go into a hot oven, and that he would go in very quickly, his face covered, his body clothed, and on his knees and elbows, and then he would come out, and in this way he did not burn and only his clothing would get hot, the fire not injuring him, and he allowed people to think this was a miracle and that he did it as a saludador. ${ }^{34}$

Having thus confessed, Gabriel was eventually sentenced by the inquisitors to 100 lashes and a two-year exile from the district. He was not condemned for having worked as a saludador, however, but for having knowingly cheated large numbers of people by taking advantage of a belief held by most of the population.

\section{True and False Saludadores}

What then was the Church's stance on saludadores? The first point to be made is that even among theologians expert on the subject, opinions varied widely and were in most cases ambiguous. For example, in about 1530, Martín de Castañega (fl. 1530) and Pedro Ciruelo (1470-1548), authors of the first two treatises on superstition written in Castilian, expressed very different points of view. As far as Castañega was concerned, saludadores' power could be explained by their "virtue", which came from their natural complexion, itself the result of the balance of the four humours therein:

It is possible that some men had such complexions that they possessed natural virtue in their breath and in their saliva, and even in their touch, due to the temperament of the complexional qualities. And thus might the four humours, which are choler and blood, phlegm and melancholy, exist in a human body in such harmony that from them there might result a hidden natural virtue ... This being so, it seems that those who demonstrate such natural virtues are not to be condemned .... and

\footnotetext{
33 “Se ponía un gusano en la voca, y dava a entender a algunos que estavan tocados de perros raviosos, y que él era saludador y que se lo quitaría. Y que hacía que un cirujano le rompiesse el pellejo, sacándole un poco de sangre, y que él llegava, chupava aquella sangre, y después la hechava en una escudilla de agua y, revuelta con ella, hechava el gusano que tenía en la voca y, como salia mezclado en la sangre que avía chupado, entendían y creýan que lo avía sacado del cuerpo del hombre, y le davan dinero y tenían por saludador, y que por gracia de Dios hacía aquellas curas." Ibid., fol. 433v.

34 "Era falso para estafar y sacar dineros, y que todos los que andavan saludando haçían lo mismo, engañando y fingiendo que tienen graçia particular de Dios. Y declaró que también entrava en un orno caliente, y que entrava muy deprissa, tapada la cara, entrando bestido y de rodillas y de codos, y luego se salía, y assí no se quemava y sólo se calentava el bestido, sin ofenderle el fuego, y dava a entender que era milagro y lo hacía como saludador." Ibid., fol. $436 \mathrm{v}$.
} 


\section{Saludadores versus Witches in Early Modern Spain}

it seems that those who possess these natural virtues which are not commonly found in men, except in a few special cases, can be called saludadores. ${ }^{35}$

Pedro Ciruelo, meanwhile, was adamant in his harsh condemnation of those who called themselves saludadores, designating them "men of superstition, sorcerers and ministers of the Devil". In his view, they were, fundamentally, impostors ("cheaters of simple folk", "cursed deceivers of the world", "contemptible drunks who travel the world proclaiming themselves saludadores"), ${ }^{36}$ whose true baseness was concealed by the signs they themselves marked on their bodies to attest their kinship with St Quiteria and St Catherine. Nevertheless, even Ciruelo was able to countenance the existence of a few exceptions to the rule, showing that belief in this myth was not limited to the popular classes, but enjoyed a level of ecclesiastical acceptance. The fact that a distinction, so typical of the time, could be drawn between "true" and "false" saludadores (however low the percentage of the former may have been), meant that faith in the supernatural powers of certain individuals remained very much intact:

It is now proven that all healing procured by words alone is a sin of superstition, and even a sin of testing God in the case of those illnesses that can be cured by natural medicines. Except when this is done by holy men, servants of God, and not by those contemptible drunks who travel the world proclaiming themselves saludadores, and be it understood that everything we have written in this chapter is against those common saludadores, not against good and simple men who by the grace of God are able to heal through their devotion, by laying on their hands and reciting prayers. But of these are there very few in the world. And, therefore, prelates and their judges must carefully examine which are the former and which the latter. ${ }^{37}$

The examinations referred to by Ciruelo were carried out by both bishops and inquisitors, and, in some cases, by local officials appointed for that specific task. ${ }^{38}$ Where it was decided that the saludador did possess special gifts which enabled him to heal in the name of God, he

\footnotetext{
35 “Podría ser que algunos hombres fuesen así complexionados que tuviesen virtud natural oculta en el aliento y en la saliva, y aun en el tacto, por razón del temperamento de las cualidades complexionales. E así podrían los cuatro humores, que son cólera y sangre, fleuma y melancolía, estar en algún cuerpo humano en tal temperamento y armonía que de allí resultase una virtud oculta natural ... De donde parece que no son de condenar los que tales virtudes naturales muestran . . . y así parece que los que tienen estas virtudes naturales que no se hallan comunmente en los hombres, salvo en pocos casos particulares, se pueden llamar saludadores." See Martín de Castañega, Tratado de las supersticiones y hechicerias (1st ed., 1529), Madrid, Sociedad de Bibliófilos Españoles, 1946, pp. $62-4$.

36 "Embaydores de la simple gente", "malditos engañadores del mundo", "borrachones viciosos que andan por el mundo en nombre de saludadores", Pedro Ciruelo, "Capitulo seteno: en que se disputa contra los comunes saludadores', in op. cit., note 1 above, pp. 100-7.

37 "Está ya probado que toda sanidad que se procura de hazer con solas palabras es pecado de superstición, y aun pecado de tentar a Dios en las enfermedades que se pueden curar por medicinas naturales. Excepto cuando esto hazen hombres santos, siervos de Dios, y no de los borrachones viciosos que andan por el mundo en nombre de saludadores, y destos se entiende todo lo que en este capítulo hemos escrito contra los comunes saludadores, no de otros hombres simples y buenos que por ventura tienen alguna gracia especial de Dios para sanar con su buena devoción, poniendo la mano y rezando buenas oraciones. Mas destos ay muy pocos en el mundo. Y, por esso, los prelados y los juezes suyos los deven bien examinar para ver quáles son de los unos, y quáles de los otros.” Ibid., p. 103.

${ }^{38}$ One notable example is known in Valencia, where, during the sixteenth and part of the seventeenth centuries there existed the post of "examinador de saludadores". As María Luz López Terrada notes, this was held for some years by a certain Domingo Moreno, a needle-maker, and himself a saludador. María Luz López Terrada, 'Las prácticas médicas extraacadémicas en la ciudad de Valencia durante los siglos XVI y XVII', Dynamis, 2002, 22: 85-120, pp. 118-19; José Rodrigo Pertegás, 'Los “saludadors” valencianos en el siglo XVII', Revista Valenciana de Ciencias Médicas, 1906, 8: 219-20.
} 


\section{María Tausiet}

was granted a licence which in effect acted as an official safe-conduct, authorizing him to travel freely from one area to the next and perform all kinds of miracles, at his own discretion. Although as the seventeenth century went on, saludadores began to fall under increasing suspicion of fraud, it is significant that even as late as 1698 , the synodal constitutions of the Archbishop of Saragossa included a clause confirming the ancient custom of bishops to grant licences to certain healers. While it is true that the intention of the text was to send out a warning about the consequences of allowing those without a licence to operate, there remained that implicit recognition of the role of the saludador per se:

We ordain that priests and their regents must not tolerate saludadores in their parishes, unless they be bearers of our written licence, in which it states that they may discharge this role, on pain of a fine of fifty reales each time, and we ordain that secular judges and council officials do not allow this either, on pain of the same fine. ${ }^{39}$

No statistics survive as to the number of such licences granted. What abundant contemporary testimony does make clear is that it was common practice to forge these documents, given that their possession added an additional and key element of verisimilitude to the role. This does not mean, however, that all licences carried by saludadores were necessarily fakes. One particularly fascinating case is that of Andrés Mascarón, who was tried in 1620 by the Inquisition in Saragossa, despite holding a number of authentic licences signed by different bishops, including the Archbishop of Saragossa. According to his own confession before the court, Andrés, originally from Salvatierra de Escá (Saragossa), had been resident in the Aragonese capital since the age of twelve, and had worked as both a tailor and a carter, but for the last three years had also worked as

a saludador, and as such had travelled around the villages of the kingdom of Aragon. And he had taken on this role because other saludadores had told him he possessed the gift to heal and to cure rabies, and that he had the wheel of Saint Catherine beneath his tongue, because he had told them he was the seventh son born to his mother. ${ }^{40}$

Whether such claims were true or not, when he was brought before the judges, Andrés presented his documents, all of which were genuine. In the end, though, he was denounced by one clergyman who had not granted him a licence: the Bishop of Barbastro, who had written a letter to the inquisitors accusing him of causing the death of a number of women in the Pyrenean village of Bielsa, after naming them as witches. In fact, having been employed by the local council and having read out a proclamation which the entire population had been called to the village square to hear, Andrés

did greet them all, and gave them an image of Christ to be kissed, and did blow upon them. And he said to the judge and council officials that the person on whom he blew hardest was a witch or

\footnotetext{
39 "Mandamos a los curas y sus regentes que no permitan en sus parroquias saludadores, si no es con expressa licencia nuestra en escrito, en que conste pueden exercitar dicho oficio, pena de cinquenta reales cada vez, y mandamos a los jurados y juezes ordinarios no lo consientan, so la misma pena." Constituciones Sinodales del Arzobispado de Zaragoza de Antonio Ibañez de la Riva, Saragossa, Pascual Bueno, 1698, fols. 471-2.

40 “. . . el ofiçio de saludador, y con occassión del ofiçio de saludador había andado por los lugares del Reyno de Aragón. Y que se puso a hazer este ofiçio porque le dijeron los saludadores que tenía virtud para saludar y curar de rabia, y que tenía la rueda de Santa Catalina devaxo la lengua, porque les había dicho era hijo seteno varón de su madre." Account of the trial of Andrés Mascarón, Archivo Histórico Nacional, Madrid, Inquisición, Libro 991, fol. $574 \mathrm{r}$.
} 


\section{Saludadores versus Witches in Early Modern Spain}

sorcerer, and that the notary should register them as such, assuring them that those he pointed to they could punish without scruple as witches, and they arrested some women on his word alone. ${ }^{41}$

In the words of another witness to the event,

He pointed to thirteen witches, five of whom he named, and they were imprisoned and four were hanged, and the other sent into exile ... and when the witness asked him how he knew them to be witches, he said that on seeing a witch he felt his flesh burn, and the older the witch the more it burned, and the village of Bielsa paid him for his work there $\ldots$ and they gave him 100 reales. $^{42}$

\section{Witch-finders}

As well as being charismatic healers, saludadores also acted as "witch-finders", and this aspect of their work was seen as essential to the smooth functioning of society. ${ }^{43}$ Not only private individuals, therefore, but also, on occasion, official bodies, from local councils to the Inquisition itself, availed themselves of their services. One very common way to point to a particular woman's guilt was to say that the putative criminal had fled her village just as a saludador was due to arrive, out of fear of being exposed as a witch. According to the report of the Archbishop of Saragossa's prosecutor from the 1591 trial for witchcraft of Bárbara Blanc, of Peñarroya de Tastavins (Teruel):

There being a man of the said village who had had no fever or other infirmity ... there was suspicion in the village that the said Bárbara Blanc had bewitched him ... and they brought in a man from outside, who was renowned for finding witches, and in the time that the latter was in Peñarroya, this defendant did not appear nor did she go into the house where the sick man lay, though it was her custom to do so. ${ }^{44}$

Similarly, according to the testimony of Martín Guillén, at the trial of Pascuala García, of Herrera de los Navarros (Saragossa):

When the inquisitors came to visit the place, as it was proclaimed in Herrera that the inquisitors were bringing with them a sorcerer to find witches, the said Pascuala went away from Herrera to the village of Azuara, where she did stay until the inquisitors had left the area. ${ }^{45}$

\footnotetext{
41 "Los saludó a todos, y dava a besar un Christo, y los soplaba. Y dixo a la justicia y jurados que a la persona a quien diese mayor soplo, aquél era bruxo o bruxa, y que el notario las asentasse por tales, asegurándoles que las que señalava, sin escrúpulo las podían castigar por bruxas, y prendieron a algunas sólo por su dicho." Ibid., fol. 574r.

42 "Señaló treçe bruxas, de las quales nombró çinco, y fueron presas y ahorcadas las quatro, y la otra desterrada ... y que, preguntándole el testigo cómo conocía las bruxas, dixo que en viendo la que era bruxa se le encendían las carnes, y más quanto más antigua lo era, y que la villa de Bielsa le pagó el trabajo de saludar... y le dieron cien reales." Ibid., fol. 574v.

${ }^{43}$ For a comparison with the "witch-finders" of England, see James Sharpe, Instruments of darkness: witchcraft in England, 1550-1750, London, Hamish Hamilton, 1996; Malcolm Gaskill, Witchfinders: a seventeenthcentury English tragedy, London, John Murray, 2005.

44 "Estando un hombre del dicho pueblo sin calentura ni otra enfermedad . . . se tuvo sospecha en el pueblo que dicha Bárbara Blanc le havía atado ... y traxeron un hombre de fuera, el qual era fama conozía brujas, y en el tiempo que aquel hombre estuvo en Peñarroya, esta respondiente no parezía ni entrava en la casa donde estava el enfermo, teniendo de costumbre entrar en la dicha casa." Trial of Bárbara Blanc, Peñarroya de Tastavins, 1591, Archivo Diocesano de Zaragoza, Saragossa, C. 1-34, fol. 24.

45 "Viniendo a visitar la tierra los señores inquisidores, como se publicó en Herrera que los inquisidores traían consigo un bruxo para conocer las bruxas, la dicha Pascuala se fue del lugar de Herrera al lugar de Azuara, donde
} 


\section{María Tausiet}

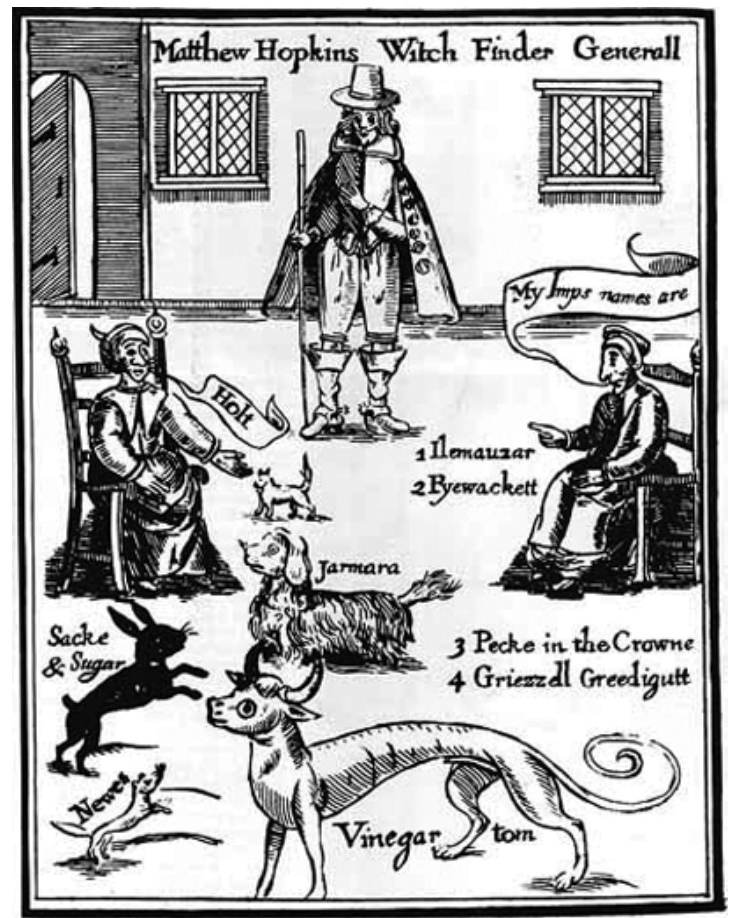

Figure 2: Matthew Hopkins, witch-finder. Aragonese saludadores had the double job of healers and witch-finders. From a broadside published by Hopkins before 1650, reprinted in Charles Mackay, Extraordinary popular delusions and the madness of crowds, London, Richard Bentley, 1841.

Such evidence of the social recognition of saludadores and of their ability to uncover the propitiatory victims that each community had to sacrifice was based, as noted above, on the position defended by the Spanish Church throughout the seventeenth century: that certain individuals did indeed possess extraordinary God-given powers. For Gaspar Navarro (fl. 1630), the natural virtue that enabled saludadores to work miracles was identifiable with their innate goodness, or at least the appearance of such goodness: "When men who live good lives, who are holy and friends of God, who are believed to have a special gift from God to heal, do heal and cure and profess a life of sanctity and recite holy prayers, then in such men can trust be placed." 46

This idea was also defended by Jaime de Corella (1657-1699) in his manual for confessors:

Penitent: Father, I confess that once I was bitten by a rabid dog and I called on a saludador, who healed me with his breath and by making the sign of the cross.

estubo hasta que los inquisidores se fueron de por esta tierra." Trial of Pascuala García, Herrera de los Navarros, 1572, Archivo Diocesano de Zaragoza, Saragossa, C. 2-12, fol. 8.

46 "Quando hombres de buena vida, santos y amigos de Dios, de quien se cree que tienen gracia especial de Dios para saludar, saludan y curan y professan vida de santidad, y dizen oraciones santas, en éstos bien se puede confiar." Navarro, op. cit., note 14 above, fol. 95. 


\section{Saludadores versus Witches in Early Modern Spain}

Confessor: And this saludador, was he a virtuous person and a man of good character?

Penitent: Father, yes he was an honest man of good repute.

Confessor: The truth is that although the common people say that saludadores have virtue, this is still an area of much suspicion ... What the Doctors of the Church say on this subject is that if the person who heals is pious and virtuous, and there is no vain circumstance in his manner of healing, it can be permitted. ${ }^{47}$

As for Andrés Mascarón (the saludador and witch-finder who wanted to deal with witches as if they actually were rabid dogs, and was responsible for the execution of a number of women in Bielsa), his trial was ultimately suspended. As far as we know, none of the witnesses testified that he was a "virtuous" man, nor "of good repute"; on the contrary, the court heard that because of his actions some of the sick people he had treated had also died. ${ }^{48}$ The accused defended himself by claiming that he healed in the names of the Holy Trinity, the Virgin Mary, St Peter, St John, St Cosmas and St Damian, St Gregory, St Augustine, St Barbara and, lastly, St Orosia, ${ }^{49}$ and, moreover, he denied any responsibility for the death sentences passed against the women found guilty of witchcraft. Mascarón's denial contradicted the allegations made by the Bishop of Barbastro, yet because of the licences in his possession, he was let off with a warning-he was no longer to practise as a saludador, if he did he would be "punished with all rigour". 50 The leniency shown by the Inquisition to this defendant contrasts starkly with the treatment shown three years later to another saludador (the bearer in this case of falsified licences) who ended up being sentenced to six years rowing in the royal galleys without pay, as well as receiving 100 lashes and being exiled from the district for ten years. ${ }^{51}$

Francisco Casabona, whose life story could have served as the plot of the kind of picaresque novel that was so popular at the time, had been born in Albero (Huesca) in 1602 and,

at the age of eight years, being in the city of Saragossa, began to serve a soldier named Morales, corporal to a captain named Felipe de Vera, and for a year and a half he travelled with him through Castile, and they went to board ship in Cartagena, where he did remain. ${ }^{52}$

\footnotetext{
47 “Pregúntase: Padre, acúsome que en otra ocasión me mordió un perro rabioso y yo llamé a un saludador, que con el aliento y hazer la señal de la cruz, me dio salud. Contesta: Y este saludador, ¿ iera persona virtuosa y de buenas costumbres? Pregúntase: Padre, sí era persona honesta y por tal reputada. Contesta: Lo cierto es que aunque el vulgo dize que los saludadores tienen virtud, no dexa de ser materia muy sospechosa ... Lo que dizen los doctores en este punto es que si la persona que cura es pía y virtuosa, y no se halla en su modo de curar alguna vana circunstancia, se puede permitir." Jaime de Corella, Practica de el confessionario, Madrid, 1690, fols. 13-14.

48 "Saying he knew how to heal all ailments, they took him to a girl who was sick, and he gave her something to drink, and soon afterwards she died." Account of the trial of Andrés Mascarón, Archivo Histórico Nacional, Madrid, Inquisición, Libro. 991, fol. 574r.

${ }^{49}$ Santa Orosia, the least-known name in this list, was the patron saint of Jaca (Huesca), famous, among other things, for curing those possessed by the devil who, from at least the thirteenth century onwards, would flock to the city on 25 June each year to be healed. See Enrique Satué Oliván, Las romerías de Santa Orosia, Saragossa, Diputación General de Aragón, 1988; Ricardo Mur Saura, Con o palo y o ropón. Cuatro estampas inéditas sobre el culto a Santa Orosia, Jaca, R Mur, 1995.

${ }^{50}$ Account of the trial of Andrés Mascarón, Archivo Histórico Nacional, Madrid, Inquisición, Libro 991, fol. $575 \mathrm{v}$

${ }^{51}$ Account of the trial of Francisco Casabona, Archivo Histórico Nacional, Madrid, Inquisición, Libro 991, fol. $639 \mathrm{v}$.

52 "Siendo de ocho años, estando en la ciudad de Çaragoça, se puso a servir a un soldado llamado Morales, cabo de esquadra de un capitán llamado Felipe de Vera, y que anduvo con el año y medio por Castilla, y se fueron a embarcar a Cartagena, adonde se quedó." Ibid., fol. 637v.
} 


\section{María Tausiet}

According to Francisco himself, it was his master who had suggested to him when he was eleven that he change his name to Sebastián Ferrer, so that he might gain his independence and begin to earn his own living. He then gave him a false licence which stated that the inquisitor-general of the kingdom of Aragon authorized him to heal as a saludador. Francisco agreed to the idea, after which

he bade farewell to the said Morales and began to practise as a saludador, making use of the said documents and patent of the Holy Office. And thus in those places people did give him what he needed in the way of food and money. And he travelled around the kingdom of Valencia, Aragon, Navarre and Catalonia as a saludador, healing men, women and cattle, and then he did go to France, and Italy and Sicily, and in all those places did present the said documents and carry out healing and they did give him everything he needed. ${ }^{53}$

In the wake of his European travels, the young Francisco began to work in "the mountains of Jaca", more specifically in the villages of El Pueyo de Jaca, Sallent de Gállego, Panticosa, Búbal, Biescas and Yésero, all situated in the Tena Valley (Huesca). From there he went to the nearby Broto Valley, but soon had to abandon his wandering life when he was brought before the inquisitors, charged with having abused the goodwill of many people by threatening to denounce them to the Inquisition if they did not give him everything he asked for. According to the judge and two council officials from El Pueyo de Jaca,

In the month of May 1623 this defendant was in the said village of El Pueyo and did present himself before them ... and did tell them he was a saludador and show them some documents and a patent saying that they had been granted by the inquisitors of Aragon ... and required that they give him favour and help to work as a saludador and that they give him food and a mount on which to go to another village. And the witnesses believing these documents to be lawful, obeyed them and called a public meeting. And when the people had gathered, this defendant did enter and there did publicly present the said documents, saying that if the officials and all those gathered did not do what was contained therein, they would incur the wrath of the inquisitors and would be subject to their penalties and censure. ${ }^{54}$

Similar threats were issued in all the other villages mentioned above. The rector of Yésero, for example, testified that Francisco had "asked for his favour and help, and for food", by virtue of the licences which he showed him, and that

although it seemed to him that these documents were not lawful, [Casabona] did make him provide lodging and that of which he had need ... And he healed men and women and cattle of that place. And because he did not give him a mount on which to travel to another village, threatening him with the Holy Office, [Casabona] said that since he was refusing to give him a mount and not

\footnotetext{
53 ،... . se despidió del dicho Morales y començó a hacer el oficio de saludador valiéndose de las dichas letras y patente del Santo Oficio. Y ansí le daban en los lugares lo que avía menester de comida y dinero. Y andubo por el reyno de Valencia, Aragón, Navarra y Cataluña como saludador, saludando hombres y mugeres, y los ganados, y que se pasó a Francia, y Italia, y Sicilia, y en todos los lugares presentaba las dichas letras y saludaba y le daban lo neçessario." Ibid., fols. 637v-638r.

54 “Por el mes de mayo de 1623 fue este reo al dicho lugar del Pueyo y se presentó ante ellos ... y les dixo que era saludador y les presentó unas letras y patente diciendo que eran concedidas por los inquisidores de Aragón ... y les requirió le diesen favor y ayuda para exercitar el oficio de saludador y le diesen de comer y cabalgadura para yr a otro lugar. Y creiendo los testigos que las dichas letras eran verdaderas, las obedecieron y juntaron público concejo. Y que estando junto el concejo, entró este reo y allí públicamente presentó dichas letras, diciendo que si los jurados y el concejo no hacían lo contenido en ellas incurrirían en indignación de los inquisidores y caerían en penas y censuras a ellos reservadas." Ibid., fol. 633r.
} 


\section{Saludadores versus Witches in Early Modern Spain}

abiding by the documents which he had presented to him, he would have him brought before the Inquisition. And he did go away most angered. ${ }^{55}$

Francisco's choice of the Tena Valley as the focus of his activities was in no way accidental. Rather than "healing" in the strict sense, his speciality lay in recognizing the area's witches, and, in the opinion of its inhabitants, there were many of them. His modus operandi was to ask for the names of all the women in a particular town or village who were suspected of witchcraft, or, if these were not forthcoming, simply for a list of all the female inhabitants. He would then mark with a cross those he considered to be witches, in order to distinguish them from the rest. One of the things reported at his trial, for example, was that in Panticosa the young man had asked a council official, "to give him the names in writing of all the women of the village so that he could mark those who were witches, and the witness did not want to give him such a list". ${ }^{56}$

Nevertheless, Francisco must have achieved his objective, since according to the testimony given by the village's rector, he presented himself at his house one day, with not only the licences supposedly granted by the Inquisition, but also

a catalogue and document in which were written the names of thirty-six women from the said village of Panticosa, and told him to guard himself against those women, since all were witches, claiming that it was through his powers as a saludador that he had recognized them. ${ }^{57}$

According to the evidence given by the judge of Búbal, Francisco himself had confessed to him, "that he wanted to go around all the villages in those mountains to discover those women who were witches, and that he would send reports on those who were that they be punished in accordance with the statutes". 58

Such statutes and laws against witchcraft proliferated during the early modern period in the Pyrenean valleys of Aragon, a fact that made it all too easy for many women to be condemned to death without proof and without any regard for statutory time limits or other proper legal procedures. In the Tena Valley, for example, a set of desaforamiento statutes had been established in 1525, which effectively enabled towns and villages to suspend the usual laws (fueros) that governed the kingdom of Aragon. These statutes are known to have remained in force throughout the sixteenth and seventeenth centuries, thanks to the discovery of documents relating to trials conducted in accordance with a similar statute promulgated in $1691 .^{59}$ Evidence of the ferocity with which witchcraft was prosecuted in the Pyrenean valleys is very scarce, and we therefore have to make do with a number of

\footnotetext{
55 “... aunque le parecía que dichas letras no eran verdaderas, le hiço dar posada y lo que hubo menester ... Y que saludó a hombres y mugeres y ganados del dicho lugar. Y porque no le dio cavalgadura para pasar a otro lugar, amenaçándole con el Santo Oficio, le dixo que pues rehusaba de darle cavalgadura y no cumplía las letras que le avía presentado, le avía de haçer yr a la Inquisiçión. Y que se fue muy colérico y enojado." Ibid., fol. 635v.

56 “... le diese nómina por escrito de todas las mugeres del lugar para señalar a las que eran brujas, y el testigo no se la quiso dar." Ibid., fol. 635r.

57 “. . . un catálogo y papel donde estaban escritas treinta y seis mugeres del dicho lugar de Panticosa, y le dixo se guardasse de aquellas, porque todas eran brujas, dando a entender que las conocía con el arte de saludador." Ibid., fol. $635 \mathrm{r}$

58 “... que quería dar buelta por todos los lugares de aquellas montañas para saber qué mugeres eran brujas, y que le embiaría memoria de las que lo fuesen para que las castigase conforme los estatutos." Ibid., fol. 636v.

${ }^{59}$ See Manuel Gómez de Valenzuela, 'El Estatuto de Desaforamiento del Valle de Tena de 1525 por delitos de brujería y hechicería', Boletín del Colegio de Abogados de Aragón, 1989, 115: 89-109.
} 


\section{María Tausiet}

disparate accounts in order to form an approximate idea of what went on at the time. One such report appears in the details pertaining to Francisco Casabona's trial, and tells of how, when he was seized by the Saragossa inquisitors, seven booklets were confiscated from him. Six contained the "names of women" which "had been given to him in certain places in the mountains of Jaca . . because they told him in those villages that the women in these lists were suspected of being witches". 60

While the Bishop of Barbastro would no doubt have been scandalized by the behaviour of this young saludador, who had managed to build a career based on institutionalized misogyny, the inquisitors' sentence stressed the (in their eyes more serious) crime of falsifying and abusing the good name of the Inquisition. The truth was that the iniquitous practice of claiming to know who was a witch and who was not, was not only limited to indigent vagabonds like Francisco, but was also one of the skills associated with medical professionals supposedly well versed in their subject and therefore, in theory, trustworthy. Such was the case with Jacinto Vargas, a 38-year-old French doctor from the BasseNavarre region (part of the historic kingdom of Navarre which would in 1660 be definitively incorporated into France), who was brought before the Saragossa inquisitors in 1636 because:

He said and did boast that he could recognize witches and knew who they were and where they gathered, declaring that in this village there were so many, and in that village there were so many more or less ... and that on being asked how he knew them, he replied that it was very easy and that whoever knew what he did would know them. ${ }^{61}$

With a flourish of fantasy and theatricality, Jacinto claimed, among other things, that

with a certain medicament that he would place in the holy water in the church font, he would ensure that if witches came to take the water they would not be able to, and would be left with their fingers in the air, shaking them as if they were playing a monochord. ${ }^{62}$

Although he was found to be "of suspect faith", and to have made an implicit pact with the devil, Jacinto defended himself by saying that he made such assertions "in order that people should believe in his knowledge ... and that they should hold him in greater esteem in those places ... to which he went to heal". Neither this nor the potential harm he might have caused those women he claimed to have recognized as witches ("he confessed that on many occasions he had said that he could find witches" $" 63$ ), prevented his eventual acquittal ("he was warned and given a reprimand, and was told he was free" ${ }^{\text {"64 }}$ ). This judgement

60 “. . . avían dado en algunos lugares de la Montaña de Jaca ... porque le decían en aquellos lugares que tenían sospecha de brujas las mugeres en ellos contenidas." Account of the trial of Francisco Casabona, Archivo Histórico Nacional, Madrid, Inquisición, Libro 991, fol. 639r-v.

61 "Deçía y se alababa que conoçía las brujas y savía quién lo eran y dónde se juntaban, declarando que en tal lugar havía tantas y en tal, tantas más o menos ... y que preguntándole cómo las conoçía, respondía que era muy fáçil y que qualquiera que supiera lo que él, las conocería." Account of the trial of Jacinto Vargas, Archivo Histórico Nacional, Madrid, Inquisición, Libro 992, fol. 251r.

62 "Con cierto medicamento que él pusiese en la pila de el agua bendita de la iglesia, haría que si las brujas llegaban a tomarla no pudiesen, y se quedarían con los dedos en el ayre, meneándolos como quien toca un monocordio." Ibid., fol. 251v. (The monochord was a musical instrument mainly used for tuning purposes. It had a single string stretched across two movable bridges.)

63 “Confessó que en muchas ocasiones havía dicho que conoçía las brujas." Ibid., fol. 252r.

64 "Fue mandado reprehender y advertir y que se fuesse libre." Ibid., fol. 252v. 
merely underlines once again the fact that what drove inquisitors was the desire not so much to bring to justice those who continued to encourage witch-hunts, but to condemn those whose claims or behaviour called the authority of the Catholic Church or the Holy Office itself into question. In this respect, the crimes of falsifying ecclesiastical documents or disobeying the tribunal were considered far more grave than that of defaming poor unhappy women by accusing them of witchcraft, despite the consequences that might ensue from such malicious allegations. ${ }^{65}$

\section{The Church's Response: Inquisition and Episcopal Justice}

The sentences imposed by the Inquisition on other alleged saludadores during the $1600 \mathrm{~s}$ serve to confirm the attitude we have been indicating thus far. For example, Juan de Mateba, a "vagrant" boy of fourteen, from Ballestar de Flumen (Huesca), who claimed to possess all sorts of curative and divinatory powers, was treated with a leniency which cannot be solely attributed to his youth. ${ }^{66}$ Apart from the fifty lashes that were to be administered "in his prison", his only punishment was to receive six years' teaching at a monastery in the city, followed by a year's exile from the bishoprics of Huesca, Jaca and Saragossa. The reprimand he was given at his trial, warning him of more serious consequences if he did not serve out his sentence, gives us an idea of his principal activities, noteworthy among them being his self-proclaimed ability to recognize witches and sorceresses:

That in future he should not heal by incantation nor staunch blood, nor should he boast of having the power to heal nor divine nor to see the dead nor other things beneath the earth, nor to recognize witches and sorceresses, on pain of 200 lashes in the city streets and other penalties to be decided on by the tribunal, and that he should not fail to attend the said monastery. ${ }^{67}$

A similar range of abilities was exhibited by Juan José de Venegas, another wandering saludador, this time originally from Constantinople. He was known as "Juan de la Cruz" and various witnesses stated that he bore the mark of the cross on his chest, and "that he said he would go into an oven when it was at its most hot and would hold a red-hot iron bar in his hands or walk on it barefoot". ${ }^{68}$ When it came to finding witches and subduing demons, he claimed that in the city of Saragossa he had

\footnotetext{
${ }^{65}$ It is worth remembering that, after being denounced, Jacinto was called to appear before the Saragossa tribunal, whereupon he fled to France and "was absent for a period of five months". After this, however, he returned "of his own volition", which was viewed in a positive light by the inquisitors. Ibid., fols. 252r-v.

${ }^{66}$ On age and its relationship with inquisitorial jurisdiction, see Henry Charles Lea, A history of the Inquisition of Spain, New York, Macmillan, 1906-7, vol. 2, pp. 3-4; Haim Beinart, 'El niño como testigo de cargo en el Tribunal de la Inquisición', in José Antonio Escudero (ed.), Perfiles jurídicos de la Inquisición española, Madrid, Universidad Complutense, 1989, pp. 391-400.

67 "Que en adelante no cure por ensalmo ni stanque sangre ni se jacte tiene gracia para curar ni adivinar ni ver los difunctos ni otras cosas debajo de tierra ni que conoce las brujas y hechiceras, so pena de dosçientos açotes por las calles públicas, y otras a arbitrio del tribunal, y que no quebrante la assistencia en dicho convento." Account of the trial of Juan de Mateba, Saragossa, 1658, Archivo Histórico Nacional, Madrid, Inquisición, Libro 998, fol. 94r.

68 "Que dezía entraría en un orno cuando estuviera más encendido y mediría una barra de yerro encendida con las manos o con los pies descalzos." Account of the trial of Juan José de Venegas, Saragossa, 1685, Archivo Histórico Nacional, Madrid, Inquisición, Libro 998, fol. 279r.
} 


\section{María Tausiet}

revealed a woman to be a witch and had reported the fact to the Inquisition. And that he knew another woman to be a witch as clearly as he knew himself to be a Christian. And that he had wanted to heal a possessed woman saying that she was a witch and that he had had her taken to the Inquisition, since he had the authority to do so. And that he had healed a possessed girl and that he had brought down the demons to her ankle and bound them there, and that he had grace and power over demons. ${ }^{69}$

Contrasting as it did with the indulgence shown towards other saludadores, the harsh sentence imposed on Juan de la Cruz reflected the tribunal's real concerns. Although he too had made defamatory and slanderous statements, boasted of his powers and issued threats against those he considered to be witches, the deciding factor in this case was that he was a newly converted Muslim, to whom, therefore, no credit at all could be given; hence, his activities were condemned as false and superstitious. Venegas himself claimed that his faith was strong, since not only had he been "baptised and confirmed in the church of St Peter in Toledo by the archbishop of that city", but he also "confessed and received holy communion every two weeks, the last time having been at the Church of the Pillar in Saragossa". ${ }^{70}$ None the less, according to the formal report read out prior to sentencing, Venegas was no more than "a man of superstition, and the more so for being a new convert, and was a deceiver and was suspected of having formed a pact with the Devil"; ${ }^{71}$ he was therefore condemned to appear at a public auto de fe wearing the insignia of an enchanter, to abjure de levi, to receive 100 lashes in the streets of the city and, lastly, to be exiled from the inquisitorial district for eight years, five of which he would serve in the royal galleys without pay.

Although we know from surviving testimonies that some saludadores, accused in the main of falsification and imposture, were found guilty, the fact is that the healing "virtue" of the majority of unofficial healers was accepted by the Church, and also by representatives of the official medical profession. In 1498, for example, a pragmatic sanction acknowledged the aptitude of so-called ensalmadores to carry out their work, despite having no qualifications; it made no mention of saludadores. ${ }^{72}$ However, ensalmadores (those who healed by reciting ensalmos-incantations, be they prayers or spells), santiguadores (those who made the sign of the cross to cure the sick), and saludadores, despite their different designations, were essentially considered to fall into a single categorypeople whose reputation as healers was founded on a combination of their own natural abilities and the magico-religious beliefs of those who came to them in search of a cure for

69 “. . . . descubierto a una muger por bruja y había dado razón dello a la Inquisición. Y que era tan cierto ser otra muger bruja como él cristiano. Y que había querido saludar a una muger espiritada diciendo era bruja y que la había de llevar a la Inquisición, pues tenía autoridad para ello.Y que había saludado a una muchacha espiritada y que había hecho bajar a los demonios al tobillo del pie y los había atado allí, y que tenía gracia y potestad sobre los demonios." Ibid.

70 "Estaba baptizado y confirmado en la iglesia de San Pedro de Toledo por el arzobispo de aquella ciudad"; “. . . confesava y comulgaba de quince a quince días, y la última vez en la iglesia del Pilar de Zaragoza." Ibid., fol. $278 \mathrm{v}$

71 “... un supersticioso, y más siendo recién convertido, y que era embustero y sospechoso de tener pacto expresso con el demonio". Ibid., fol. 279r.

${ }^{72}$ See Luis S Granjel, El ejercicio de la medicina en la sociedad española del siglo XVII, Salamanca, Universidad de Salamanca, 1971, pp. 14-16; Miguel Eugenio Muñoz, Recopilación de las leyes, pragmáticas reales, decretos y acuerdos del Real Protomedicato, Valencia, Imprenta de la Viuda de Antonio Bordazar, 1751. 


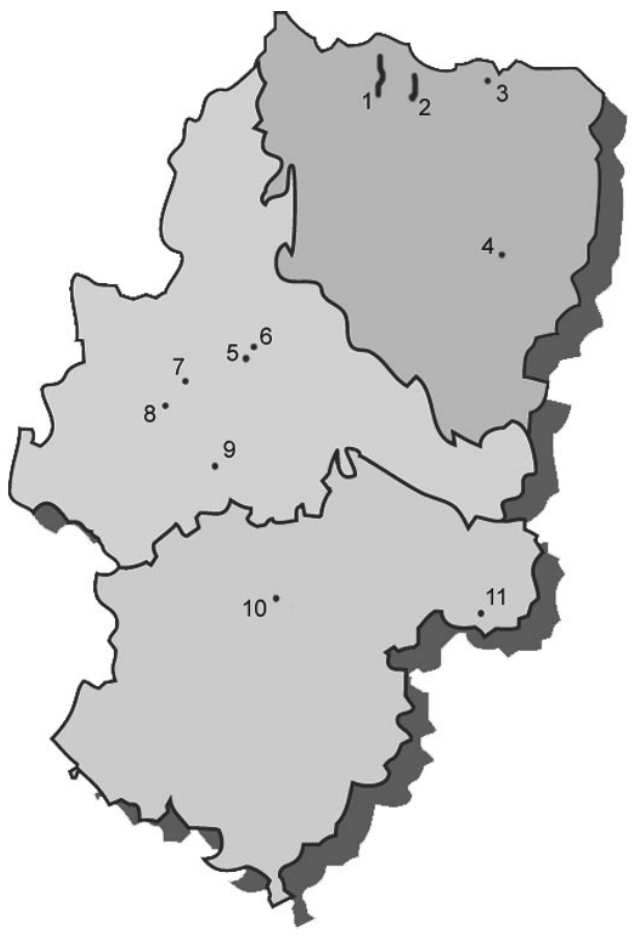

Figure 3: Map showing the places in Aragon mentioned in the text (drawn by Antonio Tausiet). Top right: Province of Huesca. 1: Tena Valley (containing the villages of El Pueyo de Jaca, Sallent de Gállego, Panticosa, Búbal, Biescas, and Yésero). 2: Broto Valley. 3: Bielsa. 4: Pozán de Vero. Centre: Province of Saragossa. 5: Saragossa. 6: Peñaflor. 7: Épila. 8: La Almunia de Doña Godina. 9: Herrera de los Navarros. Bottom: Province of Teruel. 10: La Peña del Cid (Montalbán). 11: Peñarroya de Tastavins.

their ailments. At a time when representatives of both the religious world and the scientific had, broadly speaking, the same cognitive awareness of reality as did the general public, there were no clear-cut dividing lines between the fields of science, religion and magic or superstition. $^{73}$

In fact, as far as the activities of saludadores were concerned, the two main grounds for prosecution were, firstly, financial deception and, secondly, the competition they might pose to representatives of the Church and the official medical profession. One example combining the two is the case brought by the Archbishop of Saragossa against Jaime Royo of La Peña del Cid (Teruel). As defined by one of the witnesses for the prosecution, Jaime was "a man who cures with incantations and blessings, and calls himself a soothsayer, and with these and many other things does defraud many people and receive money and other

\footnotetext{
${ }^{73}$ See María Tausiet, 'Religión, ciencia y superstición en Pedro Ciruelo y Martín de Castañega', Revista de Historia Jerónimo Zurita, 1992, 65-66: 139-48.
} 


\section{María Tausiet}

gifts from them". ${ }^{74}$ Those who came to Jaime Royo to solicit his services could compare his God-given healing powers with the authority of the Church, personified in this instance by the figure of the Archbishop's representative, or visitador. Here, the "revelation", or spontaneous confession, of one Diego Solán takes on particular significance. During an official episcopal visitation (visita) of the village of La Almunia de Doña Godina (Saragossa), Solán decided to denounce Royo, from whom he had sought advice two years earlier. He went to the visitador to ask for help in dealing with a problem of a personal nature, and laid out before him his misgivings about Royo's counsel.

In the sixteenth and seventeenth centuries, the functions performed by the clergy and by individuals such as santiguadores, ensalmadores, curanderos (healers) and saludadores were generally viewed as, to all intents and purposes, identical and interchangeable: this was the danger the Church ran by permitting certain kinds of behaviour that it could not fully control. According to Solán's detailed account, when faced with the question of whether or not his wife was a witch, he had decided to consult Jaime Royo, principally on the grounds of the latter's renown as a healer and soothsayer. In fact, Jaime was a typical saludador or witch-finder, although in this case his method of recognizing the supposed witch, and thereby confirming his client's suspicions-or granting his wishes-was far shrewder than the norm. As was described at the trial:

This witness is married ... to Catalina López, and, having his suspicions that she was a witch, because her mother was said to be a witch, in order to find out the truth, being in Blesa and some people telling him that a man from La Peña del Cid named Jaime Royo was a soothsayer, he went there and told him his purpose. And he told him to leave and that within three days he [Solán] would dream about whether she was or not, and he would see signs. ${ }^{75}$

Solán was clearly looking for an external solution to his domestic circumstances. From his point of view, a good soothsayer or witch-finder could rescue him from his predicament by making the decision for him as to the guilt or innocence of his wife. Jaime Royo, however, as a good psychologist, put the burden back on to his client's shoulders, obliging him to look inside himself and practise introspection by interpreting his own dreams. In the end, it was the husband who found an initial way out of his problems, resorting to his own imagination:

He stayed that night one league away from there with a friar of the Order of St Jerome, and did dream of naught. And the second night he slept in Blesa, and he dreamed that she was a witch, and he was much grieved, and he saw a light in the chamber and a round white shape the size of a hat. ${ }^{76}$

Three months later, Diego Solán went to visit Jaime Royo again, to ask his advice on what to do now that he had reached the conclusion that his wife, Catalina, was indeed a

\footnotetext{
74 “ ... un hombre que cura con exalmos, santiguaciones y se haze adevino, y con éstas y otras muchas cosas lleba engañadas a muchas gentes, y les lleba dineros y otras dádivas." Trial of Jaime Royo, La Peña del Cid (Teruel), 1598, Archivo Diocesano de Zaragoza, Saragossa, C. 76-23, fol. 8v.

75 "Este rebelante es casado . . con Catalina López y que, teniendo sospecha de si era bruxa, porque de su madre della se dezía que lo era, para saberlo, estando en Blesa y diziéndole algunas gentes que un hombre de La Peña del Cid que se llama Jaime Royo era adivino, fue allá y le contó su intento. Y él le dixo que se fuese y que dentro de tres días soñaría si lo era o no, y vería señales." Ibid., fol. 26r.

76 "Aquella noche durmió a una legua de allí con un frayle gerónimo, y no soñó nada. Y la segunda noche durmió en Blesa, y soñó que era bruxa, y se entristeció mucho, y vio un aclaror en el aposento y un bulto blanco redondo del tamaño de un sombrero." Ibid., fols. 26r-v.
} 
witch: "He returned three months later ... to the same Jaime Royo and did tell him what had happened to him. And Royo told him that he knew, and that he should go to his wife and that now she could do nothing to him without his feeling it." 77 Once again, his client reacted just as the saludador expected him to:

And so it was. And the first night that he slept with her, after half an hour ... he felt that something was piercing his beard, then his head, then his eyes and his ears. And that, it being dark, he did not see her hand, but he did see that she was in the bed and that she was moving, although in the morning she did deny it, saying that it was the devil who was fooling him, that it was the devil with whom he must have spoken. ${ }^{78}$

Here too, the husband was talking about his dreams, using them to prove the evil nature of his wife the witch; dreams that on this occasion he identified with reality to the point of asking Catalina to account for these stereotypical attacks, even though she could in no way be held responsible for them. The tension between the couple reached such a point that, according to the notary at the trial: "The husband did go—a year ago in March-so as not to kill her. And he did return to La Peña del Cid and speak with the same Jayme Royo." ${ }^{\text {79 In }}$ a further demonstration of shrewdness and psychological insight, Royo reproached his client for having spoken openly to his wife about the matter; however, "he should not worry about it and that, if he wanted to return home a second time, that he should hide and he would see all". 80

Despite the saludador's advice, Solán did not want to go back to his wife. About one year later, when the Archbishop's visitador arrived to carry out his inspection, Diego's insecurities came to the fore again, and he decided to consult another figure of authority and prestige, and ask him what to do. ("This witness did not want to go and wants to know what in good conscience he is obliged to do.") We do not know what the visitador's advice was, assuming that he gave any. All we do know is that Solán's attestation led to Jaime Royo's being ordered "not to bless ... nor to practise as a soothsayer", ${ }^{81}$ and that having contravened this order he was tried in 1598, by the Archbishop of Saragossa's vicargeneral, for superstition and witchcraft. This example provides a vivid illustration of the critical role assumed by the imagination, both in allegations of witchcraft and in the supposed divinatory and curative powers of saludadores. Diego Solán's account, as included in the case against Jaime Royo, highlights some of the mechanisms that were set in motion when someone decided to accuse a woman of witchcraft. Key amongst these was the process by which accusers persuaded themselves of the wickedness of the woman

\footnotetext{
77 “Volvió de allí a tres meses . . . al mesmo Jayme Royo y le dixo lo que le había sucedido. Y Royo le dixo que él lo sabía, y que fuese a su muger y que ya no le podría hazer cossa que él no la sintiesse.” Ibid., fol. 26v.

78 "Y assí, fue. Y la primera noche que durmió con ella, a media ora ... sintió que como con una barrena le andaban al derredor en la barba, y después en la mollera, en los ojos y en los hoydos. Y que, por estar ascuras, no le bio la mano a ella, pero bien hechó de ber que estaba en la cama y que se remezía, haunque a la mañana se lo negó, diziendo que era el diablo quien le engañaba, que era con quien él habría hablado." Ibid., fol. 26v.

79 "El rebelante se vino- en março hizo un año-por no matarla. Y volvió a La Peña del Cid y habló con el mesmo Jayme Royo." Ibid., fol. 26v.

80 "Jaime Royo . . . le dixo que era un nezio en habérsele descubierto, pero que no se le diese nada y que, si quería volber segunda vez a la tierra, que se escondiese y lo vería todo.” Ibid., fol. 26v.

81 “... que no santiguasse ... ni hiziesse officio de adevino”. Ibid., fol. $26 \mathrm{v}$.
} 


\section{María Tausiet}

in question; and in this respect the dream worlds of those convinced they were the victims of attacks by witches are highly revealing. ${ }^{82}$

\section{Epilogue}

From the eighteenth century onwards, belief in witchcraft underwent a major decline among the more enlightened sectors of both the Church and the world of academic medicine. ${ }^{83}$ This brought with it an increasing lack of faith in the powers of saludadores. For Feijoo, the vast majority of such men were "mere impostors", helped neither by God, nor by the Devil, nor by any natural aptitude whatsoever. In his view, rather than being healers, they were simply wandering players who flaunted their showmanship as they went from place to place, fooling a great many unsuspecting folk along the way. Without going as far as categorically denying the possibility that "among thousands" there might be one with a God-given gift for healing, Feijoo emphasized the fact that he personally had never met such a person, and ended his discourse by affirming that "it is no more probable that goblins exist than that saludadores possess healing virtue". ${ }^{84}$ None the less, despite this and other similar criticism, belief in witchcraft and a corresponding faith in the figure of the saludador persisted in many rural areas throughout the nineteenth and well into the twentieth century, even though, as time passed, both myths began to lose many of the ideas and symbols associated with them at their height. ${ }^{85}$

The witch-saludador opposition found in the sixteenth and seventeenth centuries represents a critical moment in the relationship between academic medicine, monopolized by men, and other areas of medical practice, especially those related to the world of gynaecology, that were traditionally carried out by women: a relationship that became increasingly tense as the early modern period went on. ${ }^{86}$ Significantly, a high number of midwives were accused of witchcraft — as the kind of medical assistance given to pregnant women became a lucrative activity rather than a service rendered by friends and neighbours, power conflicts were triggered, accompanied by that common feature of the age, the demonization of the person against whom one held a grievance. ${ }^{87}$

\footnotetext{
${ }^{82}$ See James S Amelang, 'Durmiendo con el enemigo: el diablo en los sueños', in María Tausiet and James S Amelang, El diablo en la edad moderna, Madrid, Marcial Pons, 2004, pp. 327-56.

${ }^{83}$ See Ole Peter Grell and Andrew Cunningham (eds), Medicine and religion in Enlightenment Europe, Aldershot, Ashgate, 2007; Owen Davies and Willem de Blécourt (eds), Beyond the witch trials: witchcraft and magic in Enlightenment Europe, Manchester, Manchester University Press, 2004.

84 “No hay más probabilidad en la existencia de los Duendes, que en la virtud de los Saludadores." Feijoo, op. cit., note 17 above, p. 18.

${ }^{85}$ See Enrique Perdiguero and Josep Maria Comelles (eds), Medicina y cultura: estudios entre la antropología y la medicina, Barcelona, Bellaterra, 2000; Enrique Perdiguero, 'Aproximación al pluralismo médico en la España de finales del siglo XIX: el uso de elementos mágicos', Medicina e Historia: Revista de estudios históricos de las ciencias médicas, 2005, 4: 1-15.

${ }^{86}$ See Montserrat Cabré i Pairet and Fernando Salmón Muñiz, 'Poder académico versus autoridad femenina: la Facultad de Medicina de París contra Jacoba Felicié (1322)', Dynamis, 1999, 19: 55-78. This article is part of the section 'Mujeres y salud: prácticas y saberes', edited by Montserrat Cabré i Pairet and Teresa Ortiz Gómez (pp. 17-400).

${ }^{87}$ See María Tausiet, 'Comadronas-brujas en Aragón en la edad moderna: mito y realidad', Manuscrits, 1997, 15: 377-92; Teresa Ortiz, 'From hegemony to subordination: midwives in early modern Spain', in Hilary Marland (ed.), The art of midwifery: early modern midwives in Europe, London, Routledge, 1993, pp. 95-114.
} 
The ambiguous and many-layered meanings of the term saludador (covering not only ensalmadores and santiguadores but also, as we have seen, certain "doctors" who claimed to be able to recognize evil witches and who held them responsible for all kinds of ailments) say much about the capital made out of a figure who gradually faded away as the belief in witchcraft declined. Subsequent generations of saludadores continued to reinvent themselves as charlatans of one kind or another, and died out for good only comparatively recently. Unlike their forebears in early modern times, however, these later incarnations posed little threat to either the Church or the medical profession. 